\title{
Effect of Seed Treatment on Seedling Health of Chili
}

\author{
M. Z. Alam, I. Hamim, M. A. Ali, and M. Ashrafuzzaman \\ Department of Plant Pathology, Bangladesh Agricultural University \\ Mymensingh-2202, Bangladesh
}

\begin{abstract}
Effect of seed treatment on seedling health of chili (BARI Morich 1) was studied at Bangladesh Agricultural University (BAU), Mymensingh, Bangladesh. BAU Bio-fungicide (3\% of seed weight), chitosan ( $1 \%$ solution), thiovit ( $0.3 \%$ of seed weight), compressed moist heat $\left(54^{\circ} \mathrm{C}\right.$ for 15 minutes), neem leaf extract $(1: 1 \mathrm{w} / \mathrm{v})$, garlic clove extract $(1: 3 \mathrm{w} / \mathrm{v})$, ginger extract $(1: 2 \mathrm{w} / \mathrm{v})$ and allamonda leaf extract $(1: 1 \mathrm{w} / \mathrm{v})$ were employed as seed treating agents. The treated seeds were placed on moistened blotter paper. Data were recorded on percent germination, production of percent healthy seedling and seedling vigour of chili. The results of seed health testing showed that, five different seed borne fungi viz. Colletotrichum capsici, Curvularia lunata, Rhizopus stolonifer, Aspergillus flavus and Fusarium moniliforme were found to be associated with the tested chili seed samples. Among these fungi, Curvularia lunata was the most prevalent one which was followed by Rhizopus stolonifer, Colletotrichum capsici, Fusarium moniliforme and Aspergillus flavus. All the seed treating agents were found to be effective compared to control in controlling seed borne fungi for the blotter method. The highest percentage of germination (93.33\%) was recorded when the seeds of BARI Morich 1 were treated with BAU Bio-fungicide, whereas the lowest percentage of germination $(61.33 \%)$ was recorded in case of untreated seeds. The highest percentage of healthy seedling $(95.33 \%)$ was recorded when the seeds were treated with BAU Bio-fungicide and allamonda leaf extracts, whereas the lowest percentage of healthy seedling $(59.00 \%)$ was recorded in case of untreated seeds. The highest vigour index (681.59) was recorded when the seeds were treated with neem leaf extracts, whereas the lowest vigour index (214.66) was recorded in case of untreated seeds.
\end{abstract}

Key Words: Seed borne fungi, BAU Bio-fungicide, Chitosan, Plant extracts, Germination, Seedling Health, Vigour Index

\section{Introduction}

Chili (Capsicum annuum) belongs to the genus Capsicum under Solanaceae family widely grown in almost all areas and seasons in Bangladesh (Asaduzzaman et al., 2010). Chili is widely grown as spice, vegetable or cash crop in the tropics. (Hemannavar, 2008). Globally chili is grown over an area of 1.5 million ha with production of 7.18 million tons (Anon., 2005).The average yield of chili in Bangladesh is 1.678 metric $\mathrm{t} \mathrm{ha}^{-1}$ which is very low compared to the yield of other chili growing countries of the world (BBS, 2010-2011). Delayed and erratic germination of chili seeds is one of the reasons of low yield of chili. There are many factors responsible for the delayed and erratic germination of chili seeds. Among the various factors, diseases are predominant. Chili suffers from many diseases caused by fungi, bacteria, viruses, nematodes and also abiotic stresses. Fungal diseases play a vital role in reducing the germination of chili. Among the fungal diseases; damping off, anthracnose or fruit rot, powdery mildew and leaf spots are the most prevalent ones. The fungi Fusarium oxysporum, Sclerotium rolfsii, and Rhizoctonia solani are soil inhabiting pathogens with wide host range and thereby, very difficult to control. The anthracnose or ripe fruit rot is a seed borne disease caused by Colletotrichum capsici (Sydow, 1913). It is a wide year spread problem limiting the profitable cultivation and seed production throughout the major chili growing regions of India. The disease has been observed to occur in three phases viz., (i) seedling blight or damping off stage, prevalent in the nursery, (ii) leaf spotting and die back stage which is initiated at different stages of growth and (iii) fruit rot stage in which especially the ripe fruits are infected. The disease is both seed borne and air borne and affects seed germination and vigour to a greater extent (Ahmed, 1982; Perane and Joi, 1988; Mesta, 1996 and Asalmol et al., 2001). Seed treatment is a process of treating seeds by any physical, chemical, biological or other agent(s) to destroy harmful seed-borne organisms or to protect the seeds against infection. It is done to prevent germination failure and seedling infection, to destroy external and internal seed borne pathogens and to develop a protective zone around the seed in the soil which protects the germinating seed and seedling from the attack of certain soil borne pathogens. To increase the production of chili qualitatively and quantitatively; farmer requires healthy and quality seeds with high percentage of germination and purity. Hence, it is imperative that seeds must be tested before they are sown in the field. Another adverse effect of seed borne pathogen is that, it will contaminate the areas which were disease free previously. So, it necessitates the eradication of seed borne inoculums through various seed treatments and through enforcement of proper domestic and international quarantine acts and procedures. Hence, the present investigation was undertaken to evaluate the effect of seed treatment with chemicals, botanicals and biological agents on prevalence of major seed borne fungi, germination, seedling health, and vigour index of chili in blotter method. 


\section{Materials and Methods}

The present investigation was carried out in the MS Laboratory, Department of Plant Pathology, Bangladesh Agricultural University (BAU), Mymensingh during November 2012 to June 2013. BARI Morich 1 was used in the experiment collected from Bangladesh Agricultural Research Institute (BARl), Joydevpur, Gazipur. Collected seed samples were stored at room temperature $\left(25^{\circ} \mathrm{C}\right)$. There were nine treatments used in this study which are as follows: $\mathrm{T}_{0}=$ Control, $\mathrm{T}_{1}=$ Seed treatment with BAU Biofungicide ( $3 \%$ of seed weight), $\mathrm{T}_{2}=$ Seed treatment with chitosan ( $1 \%$ solution), $\mathrm{T}_{3}=$ Seed treatment with thiovit $(0.3 \%$ solution $), \mathrm{T}_{4}=$ Hot water seed treatment at $54^{\circ} \mathrm{C}$ for 15 minutes, $\mathrm{T}_{5}=$ Seed treatment with neem leaf extracts $(1: 1 \mathrm{w} / \mathrm{v}), \mathrm{T}_{6}=$ Seed treatment with garlic clove extracts $(1: 3 \mathrm{w} / \mathrm{v}), \mathrm{T}_{7}=$ Seed treatment with ginger rhizome extracts $(1: 2 \mathrm{w} / \mathrm{v}) \mathrm{T}_{8}=$ Seed treatment with allamonda leaf extracts $(1: 1 \mathrm{w} / \mathrm{v})$. The extracts were prepared by using the method of Ashrafuzzaman and Hossain, 1992. For preparation of extracts, collected leaves were weighted in an electric balance and then washed in the water. After washing the large leaves were cut into small pieces. For producing extracts, weighted plant parts were pulverized in Mortar and Pestle and then distilled water was added into the pulverized plant parts. The pulverized mass was squeezed through 3 folds of fine cotton cloth. For getting 1:1 (w/v) ratio, $100 \mathrm{ml}$ of distilled water was added with $100 \mathrm{~g}$ plant parts. For getting 1:2(w/v) ratios, $200 \mathrm{ml}$ of distilled water was added with $100 \mathrm{~g}$ plant parts. For getting 1:3 (w/v) ratios, $300 \mathrm{ml}$ of distilled water was added with $100 \mathrm{~g}$ plant parts. Seeds of BARI Morich-1 were used for seed treatment. 400 seeds of each selected samples were soaked for 1 hour in chemical solution of $0.3 \%$ thiovit and $1 \%$ chitosan. Hot water seed treatment was done for 15 minutes at $54^{\circ} \mathrm{C}$. Seeds were mixed with BAU Bio-fungicide @ $3.0 \%$ of seed weight. Seeds were treated in neem leaf extract, garlic clove extract, allamonda leaf extract, and ginger rhizome extract as well as in distilled water for 1 hour as control. After 1 hour; the treated seeds were placed on moistened blotter paper at the rate of 25 seeds per plate. The test was carried out following the method of international rules for seed health testing (ISTA 1996). After incubation period, the seeds were examined under stereomicroscope for detecting the fungi grew over the germinating seeds on blotter paper. Firstly the organisms were isolated from the seeds by observing fruiting structure; thereafter the organisms were cultured in pure form on PDA. Conidia of the fungi were transferred from germinated seed surface to PDA plate with the help of sterile pointed needle. After growth of the fungal colony from the conidia, hyphal tips were transferred to another PDA plates and incubated at $28^{\circ} \mathrm{C}$ for luxuriant growth. Thus the pure culture of the pathogens was obtained. Then necessary multiplication of the pathogen was done. The plates were then placed under NUV light for maximum conidia production for 14 days at $28^{\circ} \mathrm{C}$. The identification of fungi was done based on the spore morphology and colony characters (Barnett and Hunter, 1972, Ellis, 1971). The culture was further purified by following single spore isolation technique (Tuite, 1969). Thus obtained pure culture was maintained on Potato Dextrose Agar slants. Such culture tubes were preserved in a refrigerator at $5^{\circ} \mathrm{C}$ and renewed once in a month for further studies. Data were recorded on prevalence of seed borne fungi, percent seed germination, percent healthy seedling, root length, shoot length and total length at 15 DAS. Completely Randomized Design (CRD) was followed to carry out the experiment. Each treatment was replicated thrice. The collected data on different parameters were analyzed statistically by using MSTAT C package program. The means for all the treatments were compared by DMRT (Duncan Multiple Range Test). The significance of the difference among the means was calculated by LSD test (Least Significance Difference).

\section{Results and Discussion}

In'BARI Morich 1, Colletotrichum capsici, Curvularia lunata, Aspergillus flavus, Fusarium moniliforme, and Rhizopus stolonifer were found to be associated with the untreated seeds which significantly reduced germination. Similar results were also reported by earlier worker (Bhuiyan, 1989; Kamlesh-Mathur and Mathur, 1995; Solanke et al. 2001 and Asalmol et al., 2001. All the seed treating agents completely eliminated the fungi Colletotrichum capsici and Fusarium moniliforme, Among the fungi, Curvularia lunata was the most prevalent ones followed by Rhizopus stolonifer,Colletotrichum capsici, Fusarium moniliforme and Aspergillus flavus. The highest (14.67\%) seed borne Curvularia lunata was found in case of untreated seeds, whereas the lowest $(2.00 \%)$ seed borne Curvularia lunata was found when the seeds treated with BAU Bio-fungicide + Ginger rhizome extracts. The highest $(4.67 \%)$ seed borne Aspergillus flavus was found in case of untreated seeds whereas the lowest $(2.00 \%)$ seed borne Aspergillus flavus was found when the seeds treated with allamonda leaf extracts. The highest (10.33\%) seed borne Rhizopus stolonifer was found in case of untreated seeds, whereas no seed borne Rhizopus stolonifer was found when the seeds treated with BAU Bio-fungicide, thiovit and allamonda leaf extracts (Table 1). Similar results were found by D'Souza et al. (2001), Chidanandaswamy (2001), Xiao-Fang et al. (2012) and Chookhongkha et al. In BARI Morich 1, percent seed germination, percent healthy seedling, and seedling height significantly differed in response to different seed treating agents (physical, chemicals, 
biological and botanicals) compared to control (Table $2)$. The lowest seed germination $(61.33 \%)$ was obtained from control. The highest seed germination $(93.33 \%)$ was obtained when the seed was treated with BAU Bio-fungicide followed by seed treatment with Neem leaf extract $(93.00 \%)$. Seed germination was increased by $52.18 \%$ under BAU Bio-fungicide over control. Significant differences were observed between treatments and control as well as among the treatment. The lowest percent healthy seedling (59.00\%) was obtained from control. The highest percent healthy seedling $(95.33 \%)$ was obtained when the seed was treated with allamonda leaf extract and seed treatment with BAU Bio-fungicide. Percent healthy seedling was increased by $61.58 \%$ under allamonda leaf extract and BAU Bio-fungicide over control. The highest total length $(7.53 \mathrm{~cm})$ was obtained when the seed was treated with allamonda leaf extract which was very closely followed by the seed treatment with neem leaf extract, whereas the lowest total length $(3.50 \mathrm{~cm})$ was obtained under untreated control. Total length was increased by $115.14 \%$ under allamonda leaf extracts over control. The lowest vigour index (214.66) was recorded in case of untreated seeds, whereas the highest vigour index (681.59) was recorded when the seeds were treated with neem leaf extracts which was closely followed by seed treatment with BAU Biofungicide and allamonda leaf extracts (Table 2). In the present study; BAU Bio-fungicide, all the botanicals significantly reduced seed borne fungal pathogens of chili, simultaneously increased the germination percentage and enhanced the growth characters of chili seedling. The similar results in reducing percent seed borne fungal pathogens, increasing percent germination and enhancing growth characters of vegetable seedling were also found by the reports of Islam et al., (2006); Hossain et al. (2005); Howlader (2003); Rahman et al., (1999); Rahman et al., (2012); Khan (1999); Mahfuzul (1997); Kurueheve and Padmavathi (1997); Suratuzzaman (1995); Khan and Fakir (1995); Arun et al. (1995); Hashim et al. (1992), Assadi and Behroozin (1987), LU Chang-min et al. , and S. Photchanachai et al..

Table 1. Effect of seed treatment on prevalence of $\%$ seed borne fungi of chili (Variety BARI Morich 1) at 15 DAS in blotter method

\begin{tabular}{ccccccc}
\hline Treatments & $\begin{array}{c}\text { Colletotrichum } \\
\text { capsici }\end{array}$ & $\begin{array}{c}\text { Curvularia } \\
\text { lunata }\end{array}$ & $\begin{array}{c}\text { Aspergillus } \\
\text { flavus }\end{array}$ & $\begin{array}{c}\text { Fusarium } \\
\text { moniliforme }\end{array}$ & $\begin{array}{c}\text { Rhizopus } \\
\text { stolonifer }\end{array}$ & $\begin{array}{c}\text { Total } \\
\text { mons }\end{array}$ \\
\hline $\mathrm{T}_{0}$ & 5.67 & 14.67 & 4.67 & 5.33 & 10.33 & 41.00 \\
$\mathrm{~T}_{1}$ & 0.00 & 2.00 & 2.67 & 0.00 & 0.00 & 4.67 \\
$\mathrm{~T}_{2}$ & 0.00 & 6.00 & 5.00 & 0.00 & 3.33 & 14.33 \\
$\mathrm{~T}_{3}$ & 0.00 & 3.00 & 4.33 & 0.00 & 0.00 & 7.33 \\
$\mathrm{~T}_{4}$ & 0.00 & 4.00 & 4.00 & 0.00 & 3.67 & 11.67 \\
$\mathrm{~T}_{5}$ & 0.00 & 3.00 & 4.00 & 0.00 & 2.00 & 9.00 \\
$\mathrm{~T}_{6}$ & 0.00 & 4.00 & 4.33 & 0.00 & 0.00 & 8.33 \\
$\mathrm{~T}_{7}$ & 0.00 & 2.00 & 3.33 & 0.00 & 1.00 & 6.33 \\
$\mathrm{~T}_{8}$ & 0.00 & 2.67 & 2.00 & 0.00 & 0.00 & 4.67 \\
\hline
\end{tabular}

Table 2. Effect of seed treatment on germination, production of healthy seedling and seedling vigour of chili at 15 DAS in blotter method

\begin{tabular}{ccccccc}
\hline Treatments & \% Germination & $\begin{array}{c}\text { \% Healthy } \\
\text { seedling }\end{array}$ & $\begin{array}{c}\text { Root length } \\
(\mathbf{c m})\end{array}$ & $\begin{array}{c}\text { Shoot length } \\
(\mathbf{c m})\end{array}$ & $\begin{array}{c}\text { Total length } \\
(\mathbf{c m})\end{array}$ & Vigour index \\
\hline $\mathrm{T}_{0}$ & $61.33 \mathrm{e}$ & $59.00 \mathrm{e}$ & $2.17 \mathrm{c}$ & $1.33 \mathrm{~d}$ & $3.50 \mathrm{~d}$ & 214.66 \\
$\mathrm{~T}_{1}$ & $93.33 \mathrm{a}$ & $95.33 \mathrm{a}$ & $3.50 \mathrm{~b}$ & $3.00 \mathrm{a}$ & $6.50 \mathrm{~b}$ & 606.65 \\
$\mathrm{~T}_{2}$ & $85.00 \mathrm{~b}$ & $85.67 \mathrm{~d}$ & $4.00 \mathrm{ab}$ & $1.83 \mathrm{c}$ & $5.83 \mathrm{~b}$ & 495.55 \\
$\mathrm{~T}_{3}$ & $83.33 \mathrm{~b}$ & $92.67 \mathrm{ab}$ & $2.67 \mathrm{c}$ & $1.17 \mathrm{~d}$ & $3.83 \mathrm{~cd}$ & 319.15 \\
$\mathrm{~T}_{4}$ & $78.67 \mathrm{c}$ & $88.33 \mathrm{c}$ & $3.83 \mathrm{ab}$ & $2.33 \mathrm{~b}$ & $6.17 \mathrm{~b}$ & 485.39 \\
$\mathrm{~T}_{5}$ & $93.00 \mathrm{a}$ & $91.00 \mathrm{~b}$ & $4.33 \mathrm{a}$ & $3.00 \mathrm{a}$ & $7.33 \mathrm{a}$ & 681.69 \\
$\mathrm{~T}_{6}$ & $62.00 \mathrm{e}$ & $91.67 \mathrm{~b}$ & $3.67 \mathrm{~b}$ & $2.67 \mathrm{ab}$ & $6.33 \mathrm{~b}$ & 392.46 \\
$\mathrm{~T}_{7}$ & $74.33 \mathrm{~d}$ & $93.67 \mathrm{ab}$ & $2.67 \mathrm{c}$ & $1.83 \mathrm{c}$ & $4.50 \mathrm{c}$ & 334.49 \\
$\mathrm{~T}_{8}$ & $78.33 \mathrm{c}$ & $95.33 \mathrm{a}$ & $4.43 \mathrm{a}$ & $3.10 \mathrm{a}$ & $7.53 \mathrm{a}$ & 589.82 \\
\hline $\mathrm{LSD}$ & 3.08 & 2.51 & 0.58 & 0.42 & 0.80 &
\end{tabular}

Values within the same column having a common letter(s) do not differ significantly ( $\mathrm{P}=0.01)$

$\mathrm{T}_{0}=$ Control, $\mathrm{T}_{1}=$ Seed treatment with BAU Bio-fungicide ( $3 \%$ of seed weight $), \mathrm{T}_{2}=$ Seed treatment with chitosan $\left(1 \%\right.$ solution), $\mathrm{T}_{3}=$ Seed treatment with thiovit $(0.3 \%$ solution $), \mathrm{T}_{4}=$ Hot water seed treatment at $54^{\circ} \mathrm{C}$ for 15 minutes, $\mathrm{T}_{5}=$ Seed treatment with neem leaf extracts $(1: 1 \mathrm{w} / \mathrm{v}), \mathrm{T}_{6}=$ Seed treatment with garlic clove extracts $(1: 3 \mathrm{w} / \mathrm{v}), \mathrm{T}_{7}=$ Seed treatment with ginger rhizome extracts $(1: 2$ $\mathrm{w} / \mathrm{v}) \mathrm{T}_{8}=$ Seed treatment with allamonda leaf extracts $(1: 1 \mathrm{w} / \mathrm{v})$. 


\section{Conclusion}

Seed borne fungal pathogens cause enormous economic losses to the chili growers of all over the worlds especially in Bangladesh by preventing germination, inducing seedling mortality as well as morphological disorder, and reducing seedling vigour. The results of the present investigation showed that, seed treatment with different physical, chemicals, biological and botanical agents especially BAU Biofungicide, allamonda leaf extracts, neem leaf extracts and chitosan solution will be helpful to prevent germination failure, to produce healthy, disease free and morphologically strong seedling and to promote production of vigorous seedling which is considered as effective, economic, and eco-friendly disease management strategy. Among different seed treating agents, BAU Bio-fungicide has been proved as the best seed treating agent in controlling different seed borne fungi which is closely followed by allamonda leaf extracts, chitosan solution, garlic extracts and neem leaf extracts.

\section{References}

Ahmed, S.S. 1982. Studies on Seed Borne Aspects of Anthracnose of Chillies Caused by Colletotrichum capsici (Sydow.)Butler and Bisby.M. Sc. (Agri.) Thesis, University of Agricultural Sciences, Bangalore.

Anonymous. 2005. FAO Statistical Year Book, Publishers Food and Agriculture Organization of UN, Rome, pp.75-76.

Arun, A., Rekha, C. and Chitra, A. 1995. Effect of Alicia and Extracts of Garlic and Bigononia on Two Fungi. Indian Journal of Mycology and Plant Pathology 25(3): 316-318.

Asaduzzaman, M., Alam M.J. and Islam, M.M. 2010. Effect of Trichoderma on Seed Germination and Seedling Parameters of Chilli. Journal of Science Foundation, 8 (1\&2):141-150.

Asalmol, M.N. Kale, V.P. and Ingle, S.T. 2001. Seed Borne Fungi of Chilli, Incidence and Effect on Seed Germination. Seed Res., 29(1): 76-79.

Ashrafuzzaman, H. and Hossain, I. 1992. Antifungal Activity of Crude Extracts of Plants against Rhizoctonia solani and Bipolaris sorokiniana. Proc, BAU. Res. Prog., 6: 188-192.

Assadi, and Behroozin, M. 1987. The Effect of Bulb Extracts of Onion and Garlic on the Mycelial Growth of Fusarium spp. Sclerotium cepivorum. Iranian Journal of Plant Pathology 23(1-4): 1 -3.
Bangladesh Bureau of Statistics. 2011. Yearbook of Agricultural Statistics of Bangladesh, pp: 38.

Barnett, H.L. and Hunter, B.B. 1972. Illustrated Genera of Imperfect Fungi. Burgess Publication Ltd, St. Paul, Minnesota, USA, pp.241.

Bhuiyan, K.A. 1989. Prevalence of Seed Borne Fungi Associated with Chilli Seeds, Abstract of Annual Research Review; 23pp. Bangabandhu Sheikh Mujibur Rahman Agricultural Universityr, Salna, Gazipur, Bangladesh.

Chidanandaswamy, B.S. 2001. Studies on Colletotrichum capsici (Syd.) Butler and Bisby Causing Leaf Spot of Turmeric (Curcuma longa L.). M.Sc.(Agri.) Thesis, University of Agricultural Sciences, Dharwad.

Chookhongkha, N. Sopondilok, T. Photchanachai, S 2012. Effect of Chitosan and Chitosan Nanoparticles on Fungal Growth and Chilli Seed Quality. ISHS Acta Horticulturae 973: International Conference on Postharvest Pest and Disease Management in Exporting Horticultural Crops - PPDM.

D'Souza, A. Roy, J.K. Mohanty, B. and Dasgupta, B. 2001. Screening of Trichoderma harzianum against Major Fungal Pathogens of Betelvine. Indian Phytopathology, 54: 340-345.

Ellis, M.B. 1971. Demataceous hyphomycetes, Commonwealth Mycological Institute, Ferry Lane, Kew Surrey, UK pp.680.

Hemannavar, V. 2008. Studies on Seed Borne Aspects of Anthracnose of Chilli and Its Management. MS Thesis, Department of Plant Pathology, College of Agriculture, University of Agricultural Sciences, Dharwad-580005.

Hossain, M.M. Khalequzzaman, K.M. Aminuzzaman, F.M. Mollah, M.R.A. and Rahman, G.M.M. 2005. Effect of Plant Extract on the Incidence of Seed-Borne Fungi of Wheat. J. of Agric. and Rural Dev., 3(1,2).39-43.

Howlader, A.N. 2003. Effect of Seed Selection and Seed Treatment on the Development of Phomopsis Blight and Fruit Rot of Egg Plant. MS Thesis. Dept. of Plant Pathology, BAU, Mymensingh, Bangladesh.

Islam, M.A. Aminuzzaman, F.M. Islam, M.R. and Zamal, M.S, 2006. Seed Treatment with Plant Extract and Vitavax-200 in Controlling Leaf Spot (Bipolaris Sorokiniana) with Increasing Grain Yield of Wheat. Int. J. of Sustain. Agril. Tech., 2(8): 15-20. 
ISTA. 1996. International Rules of Seed Testing Association. In. Proc. Int. Seed Test. Assoc. P. $19-41$.

Kamlesh, M. and Mathur, K. 1995.Bioassay of Culture Filtrates of Isolates of Colletotrichum capsici on Seeds, Seedlings and Fruits of Chilli. Indian Journal of Mycology and Plant Pathology. 23(3):312-313.

Khan, A.A. and Fakir, G.A. 1995. Seed Treatment with Garlic Extract to Control Seed-Borne Pathogen of Jute. Bangladesh Journal of Plant Pathology, 11(1-2).

Khan, N.U. 1999. Studies on Epidemiology, Seed Borne Nature and Management of Phomopsis Fruit Rot of Brinjal. MS Thesis. Dept. of Plant Pathology. BAU, Mymensingh, Bangladesh.

Kurucheve, V. and Padmavathi, R. 1997. Effect of Seed Treatment with Plant Products on Seed Germination, Growth and Vigour of Chilli Seedlings (K-1). Indian Pathology. 50(4): 529530.

Mahfuzul, H. 1997. Control of Major Seed Borne Fungi of Chilli (Capsicum annuum L.). MS Thesis. Department of Plant Pathology, BAU, Mymensingh, Bangladesh.

Mesta, R.K. 1996. Studies on Fruit Rot of Chilli Caused by Colletotrichum capsici (Sydow.) Butler and Bisby. M.Sc.(Agri.) Thesis, University of Agricultural Sciences, Dharwad.

Perane, R.R. and Joi, M.B. 1988. Studies on Seed Borne Infection of Fruit Rot and Dieback of Chillies. J. Maharashtra Agric. Univ., 13: 231232.

Photchanachai, S. Singkaew, J. Thamthong, J. 2012, Effects of Chitosan Seed Treatment on
Colletotrichum sp. and Seedling Growth of Chili cv. 'Jinda.' ISHS Acta Horticulturae 973: International Conference on Postharvest Pest and Disease Management in Exporting Horticultural Crops,PPDM.

Rahman, G.M.M. Islam, M.R. and Wadud, M.A. 1999. Seed Treatment with Plant Extracts and Hot Water: A Potential Biological Method of Controlling Seed Borne Infection of Wheat. Bangladesh Journal of Training and Development. 12(1-2): 185-190.

Rahman, M.A. Sultana, R. Begum, M.F. Alam, M.F. 2012. Effects of Culture Filtrates of Trichoderma on Seed Germination and Seedling Growth in Chilli. International Journal of Biosciences, 2( 4) : 46-55.

Solanke, R.B. Deosarkar, D.B. and Jawale, L.N. 2001: Seed Borne Fungi of Chilli and Response of Fusarium moniliforme to Various Seed Dressers. J. Maharashtra Agric. Univ., 26(2): 187-188.

Suratuzzaman, M. 1995. Studies on the Seed Borne Fungi of Soybean and Its Control. MS Thesis. Dept. of Plant Pathology, BAU, Mymensingh, Bangladesh.

Sydow, H. 1913. Vermicularis capsici. Annuals of Mycologia, 11: 329.

Tuite, J. 1969. Plant Pathological Methods, Fungi and Bacteria, Vol. I. Burgess Publishing Co., Minneapolis, USA, pp.238.

Xiao-Fang, L.; Xiao-Qiang, F.; Sheng Y.; Ting-Pu, W. and Zhong-Xing, S. 2012. Effects of Molecular Weight and Concentration of Chitosan on Antifungal Activity against Aspergillus niger. Plant Protect. Sci., 48(4): 170-178. 